\title{
Flash floods in Catalonia: a recurrent situation
}

\author{
M. C. Llasat ${ }^{1}$, M. Llasat-Botija ${ }^{1}$, A. Rodriguez ${ }^{1}$, and S. Lindbergh ${ }^{2}$ \\ ${ }^{1}$ Department of Astronomy and Meteorology, Faculty of Physics, University of Barcelona, Spain \\ ${ }^{2}$ University of Montpellier III, Montpellier, France
}

Received: 19 March 2010 - Revised: 24 April 2010 - Accepted: 27 July 2010 - Published: 14 September 2010

\begin{abstract}
This work focuses on the analysis and characterization of the flash flood events occurring during summer in Catalonia. To this aim, a database with information about the social impact produced by all flood events recorded in Catalonia between 1982 and 2007 has been built. The social impact was obtained systematically on the basis of news press data and, occasionally, on the basis of insurance data. Flood events have been classified into ordinary, extraordinary and catastrophic floods, following the proposal of Llasat et al. (2005). However, bearing in mind flash flood effects, some new categories concerning casualties and car damage have also been introduced. The spatial and temporal distribution of these flood events has been analyzed and, in an effort to better estimate the social impact and vulnerability, some indicators have been defined and analyzed for a specific region. These indicators allow an analysis of spacial and temporal trends as well as characterization of the events. Results show a flash-flood increase in summer and early autumn, mainly due to inter-annual and intra-annual changes in population density.
\end{abstract}

\section{Introduction}

Floods are a complex hydrometeorological hazard. Meteorological and climatic factors, drainage basin factors, drainage network, channel morphometry and human factors play a major role. For regions such as Eastern Spain, the South of France, Italy and the West of Balkan Peninsula, flash-floods are not infrequent and can be considered a climatic feature. They are object of study of international projects such as FLASH (Llasat et al., 2009a) or HYDRATE (Gaume et al., 2009). However, in the Spanish case, there is no systematic

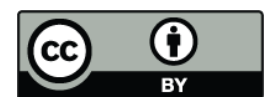

Correspondence to: M. C. Llasat (carmell@am.ub.es) information about flow values during flash floods (on some occasions no gauge exists in the catchment areas due to their non-permanent flow). There is accordingly a need to work on the basis of indirect information collected from meteorological data, impacts and observations. In this case it is usual to classify flood events on the basis of their impact (Brazdil et al., 1999; Barriendos et al., 2003), the convective features and rainfall intensity (Llasat, 2001) or the structure of the precipitation system (Rigo and Llasat, 2004).

Following these previous works and trying to build an integrated approximation to the different scenarios of flood risk (Llasat and Siccardi, 2010), Llasat (2009) has proposed a qualitative floods classification, taking into account the main characteristics of the precipitation event, size and slope of catchments, and the potential impact of the floods. The last objective of a classification like this is giving synthetic information useful for Civil Protection. The principles of this classification have been already applied in Barrera et al. (2006), Barnolas and Llasat (2007) and Llasat et al. (2008). Following this proposal (that will not be developed here), flash floods in West Mediterranean region can be classified into two types. Type 1 considers short-lived local events $(<3 \mathrm{~h}$, usually $<1 \mathrm{~h})$ of very intense precipitation (peaks above $3 \mathrm{~mm} / \mathrm{min}$ ) that do not surpass $100 \mathrm{~mm}$. They are associated with strongly convective rainfall events (Llasat, 2001) produced by isolated cells or multicells (Rigo and Llasat, 2004), that affect little basins with strong slopes. Although some casualties can be produced by this kind of flash-flood (mainly as a consequence of the imprudent behaviour of people), damage is usually ordinary or extraordinary (Barriendos et al., 2003) (i.e. damage to cars placed near the river or in its bed). We could call them as shortlived/extraordinary events. On the other hand, flash floods of type 2 usually cause catastrophic damages (Barriendos et al., 2003). Indeed, although they last less than $24 \mathrm{~h}$ and the maximum precipitation is usually recorded in less than $6 \mathrm{~h}$, accumulated rainfall can exceed $200 \mathrm{~mm}$. They are strongly

Published by Copernicus Publications on behalf of the European Geosciences Union. 
convective events (Llasat, 2001) produced by multicells or mesoscale convective systems (Rigo and Llasat, 2004) that usually remain stationary, quasi-stationary or associated with convective rains, and that can affect little and medium size basins. Then, we could call them as short-lived/catastrophic events. In this sense, the return period of these last events is above the return period of the extraordinary ones.

Autumn is the most flood-prone season in Catalonia (Barnolas and Llasat, 2007), but the distribution of convective rainfall (Llasat, 2001) points to summer as the most probable season for flash-flood generation. Bearing in mind that flash-floods usually affect the coastal region and mountain region in holiday season, the increase of vulnerability (as a consequence of the urban development in flood prone areas), and exposure (as a consequence of the great increase of population and tourism in summer season) makes these phenomena a substantial risk.

This paper analyzes flood distribution and flash floods in Catalonia over a period of 26 years (1982-2007) for which data on impact are available, and it makes particular reference to their social impact, taking into account the increase of population density in flood-prone areas.

\section{Methodology}

This work is centred in the analysis of the period 1982-2007. The sources of information were:

- the INUNGAMA database (Barnolas and Llasat, 2007): it is a GIS and ACCESS database developed by some of the authors and other members of their team (GAMA) which contains systematic information about all the floods recorded in Catalonia since 1900;

- the PRESSGAMA database (Llasat et al., 2009b): it is an ACCESS database developed by the GAMA team that contains more than 14000 news items about natural hazards and climate change, published by the "La Vanguardia" newspaper and complemented by other newspapers, since 1982;

- some scientific and technical publications devoted to specific floods that have affected Catalonia (i.e. Llasat and Rodríguez, 1992; Pascual, 1999; Ramis et al., 1994; Guijarro, 1997; Llasat et al., 2003)

The criteria to define a day of flood and a flood event is based in these ones applied when flood series are built (i.e. Brazdil et al., 1999; Barriendos et al., 2003; Glaser et al., 2003; Barnolas and Llasat, 2007). The following criteria were used:

- One day of flood is a day in which one or more floods occurred. One flood event is this one that can be produced by a meteorological episode that can last more than one day and that can register the overflow of one or more rivers and stream flows.
- An event is considered as a flash-flood if its duration is equal to or shorter than one day.

- Following Barriendos et al. (2003) and Llasat et al. (2005), ordinary floods or simple high waters are events characterized by the increase in the flow of fluvial courses, without causing overflow in their banks. Such episodes can cause damages if activities are being carried out in or near the river or torrent at the time; they will be identified by category 0 . Extraordinary floods (category 1) are produced by precipitation episodes which cause overflowing of banks of an intensity or duration which does not cause serious damage in the locality. Usually, these episodes can cause discomfort and inconvenience to the daily life of the population, but sometimes they can produce some damages in those structures placed near the river. We include here the inundation of basements as a consequence of drainage problems (as is the case of Barcelona city, where torrents are covered). Finally, catastrophic floods (category 2) are produced by the overflowing of banks leading to serious damage or destruction of infrastructure (bridges, mills, walls, and paths), buildings, livestock or crops. This kind of classification has been applied to historical and recent floods, but it does not consider the casualties due to different criteria when historical archives are analyzed. Then, to take account of flash-flood effects, a new category concerning casualties (5) and car damage has also been introduced ( 0.5 if the flood swept away some cars)

- The identified events were checked using the various sources of information.

In order to better estimate social impact and vulnerability some indicators have been defined and analyzed for specific cases and a specific region. Besides the indicators applied in the Plan to obtain the cartography of flood risk in Catalonia, called INUNCAT (http://www.gencat.cat/interior/ esc/docs/INUNCAT.pdf), others such as the number of cars affected or the number of requests received by the meteorological service, as well as the indicators proposed by Messner and Meyer (2006) and Blaikie et al. (1994) have been also taken into account. These indicators allow analysis of spatial and temporal distributions as well as characterization of events (Fig. 1). In this paper, we have classified the events in ordinary (0), extraordinary (1) or catastrophic (2) ones in basis to the direct material damage. Human fatalities are considered in a parallel classification (5), as well the fact that the flood swept away some cars. For instance, an event can be of type 0 and 5 (although it is not usual it is not impossible, due to an imprudent behaviour). 


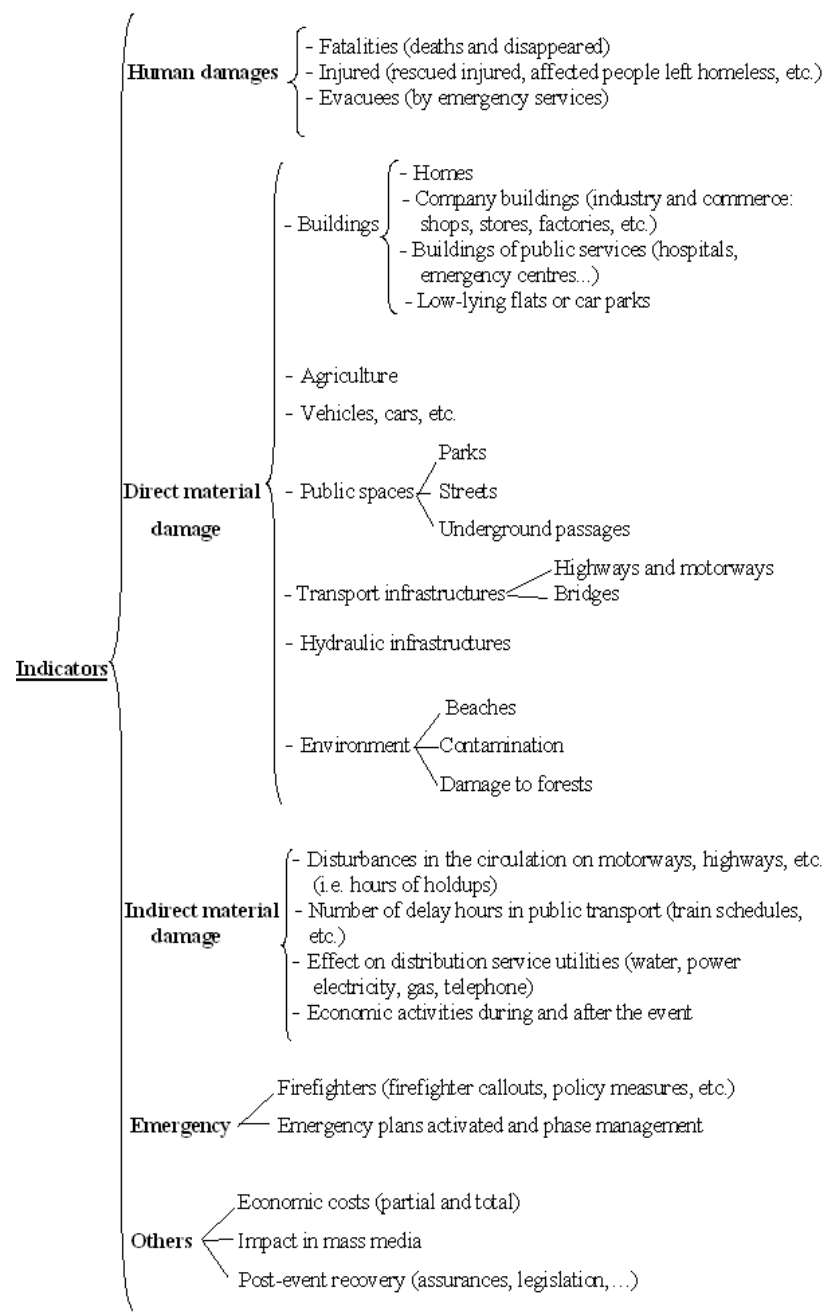

Fig. 1. Scheme of potential variables that can be considered to analyse the societal impact.

\section{Spatial and temporal distribution}

A total of 202 rainfall episodes which generated floods in the area (flood events) have been identified for the period 19822007. This fact shows a considerable increase in comparison with the 217 flood events identified for the 20th century in Barnolas and Llasat (2007). After the present study that has allowed the systematic analysis of the daily press since 1982 (Llasat et al., 2009b), the final figure for the period 19002007 is of 356 flood events, 289 of them during the $20^{\text {th }}$ century. This change confirms that an in deep analysis of daily press for the period 1900-1981, could increase the total number of events identified for the 20th century, including ordinary floods.

Table 1 shows the distribution of 196 events (there is not enough information to classify 6 events). 54\% of the events have been classified as "extraordinary" and $17 \%$ of them have produced casualties. It is interesting to see that $14 \%$

\section{Number of flood events in Catalonia (1982-2007)}

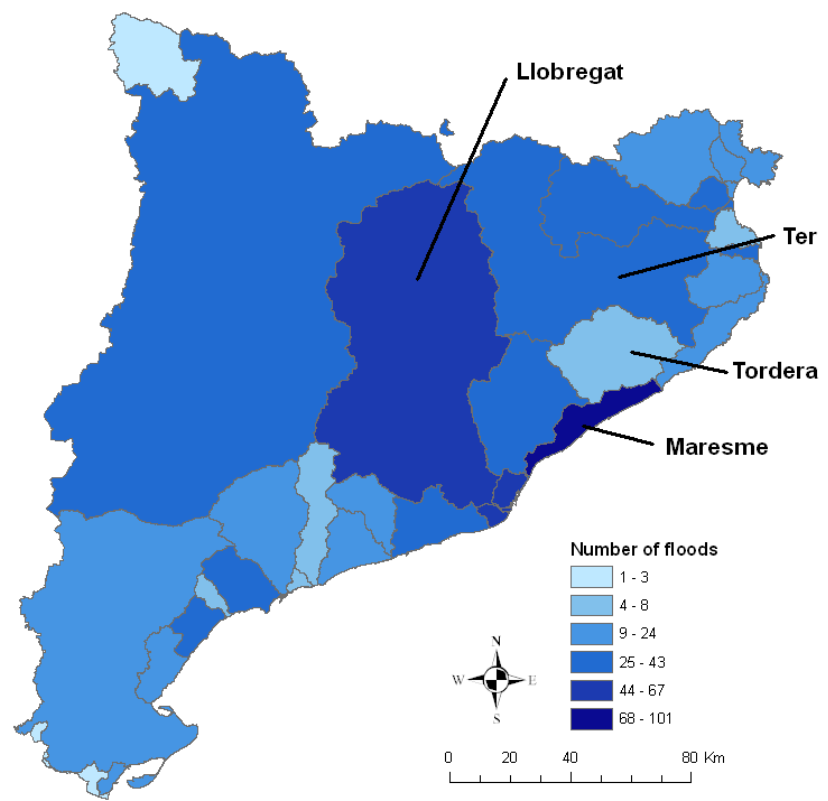

Fig. 2. Distribution of flood events by river basins, recorded in Catalonia between 1982 and 2007. The basins cited in the text are showed.

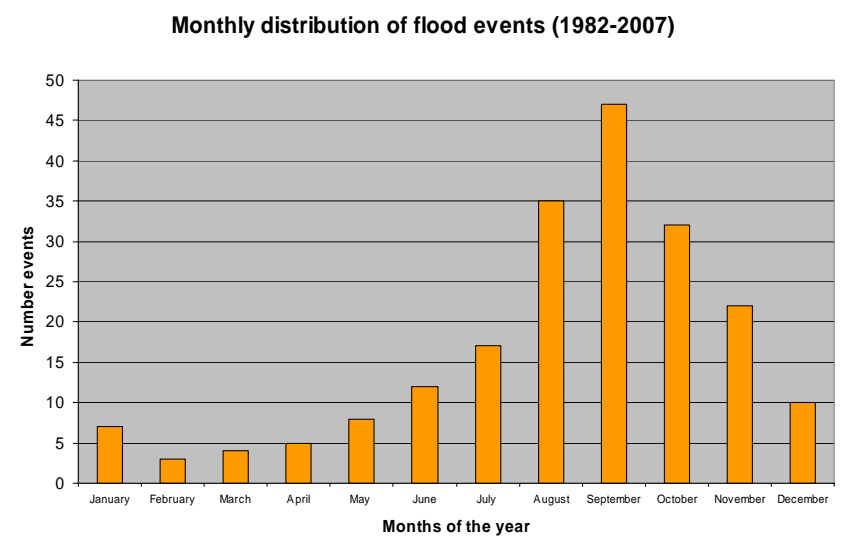

Fig. 3. Monthly distribution of flood events recorded in Catalonia (1982-2007).

of the ordinary flood events have also produced casualties and $10 \%$ of them have swept away some cars. Obviously, catastrophic events have the major percentages of casualties.

Most of the flood events have affected the Llobregat basin, near the coast, and the Maresme basin, with a total number of 67 and 101, respectively (Fig. 2). September has recorded the maximum number of floods $(23 \%)$ followed by August and October with $17 \%$ and $16 \%$ of the total, respectively (Fig. 3). February has recorded less than $1 \%$. As a consequence, the 
Table 1. Distribution of the number of flood events by category. Columns two and three show the number of each type of flood events that have swept away some cars $(0,5)$ or that have produced casualties (5).

\begin{tabular}{lccc}
\hline & Number events & Category 0,5 & Category 5 \\
\hline Ordinary & 82 & 9 & 12 \\
Extraordinary & 105 & 31 & 18 \\
Catastrophic & 9 & 4 & 6 \\
TOTAL & 196 & 44 & 36 \\
\hline
\end{tabular}

season with the maximum number of flood days is summer if considered as the JAS months (Fig. 4a), or autumn, if considered as SON (Fig. 4b). This simple observation is important when seasonal analyses are undertaken. The comparison with the distribution obtained for the period 1901-2000 (Barnolas and Llasat, 2007) shows a decrease in the contribution of the month of October to the average annual number of flood events (24\% for the 20th century) and an increase for the month of September ( $20 \%$ for the 20 th century), which is probably related with the increase of population density in coastal areas (Llasat et al., 2008), where high rainfalls and floods mainly arise during summer or the beginning of autumn.

Figure 5 shows the distribution obtained for flash-floods and no flash floods: $82 \%$ of the flood events were related with flash-floods. The monthly distribution is similar to this one corresponding to the total number of floods, with September as the month with the highest number (22\%).

The temporal evolution of flood events shows a positive trend that cannot be completely justified by changes in the press coverage (Fig. 6). Although press coverage on natural risks and climate change has experienced a strong rise in the last decades (Llasat et al., 2009b), there is not a clear trend in the number of news about floods (Llasat et al., 2009c). Barnolas and Llasat (2007) have found a positive trend that is statistically significant at $95 \%$ confidence level following the Monte Carlo procedure, with a smooth increase in the number of floods ( 2 floods per century) over the last 30 years of $20^{\text {th }}$ century. The same authors show that this trend is due to the growth in the number of floods in the littoral in recent years, mainly in the Maresme, Tordera and basins placed at the north of Ter River. Due to the lack of systematic data about flow of torrential water courses, it is not possible to relate this increase with flow changes. Thus it is only possible to assess the rise in the frequency of events that affect the population, a result that is consistent with the greater occupation of flood-prone areas and greater exposure, in addition to changes in land use (Llasat et al., 2008). The monthly analysis corroborates the strong summer contribution to this evolution; in fact, the highest positive trend has been found for September (6 floods/century), followed by
Seasonal distribution of floods (summer=JAS) 1982-2007

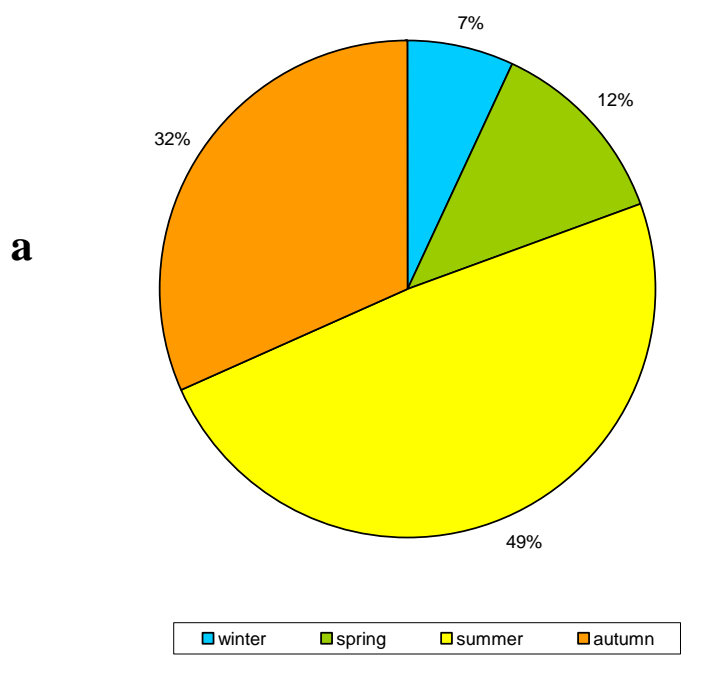

Seasonal distribution of floods (summer=JJA) 1982-2007

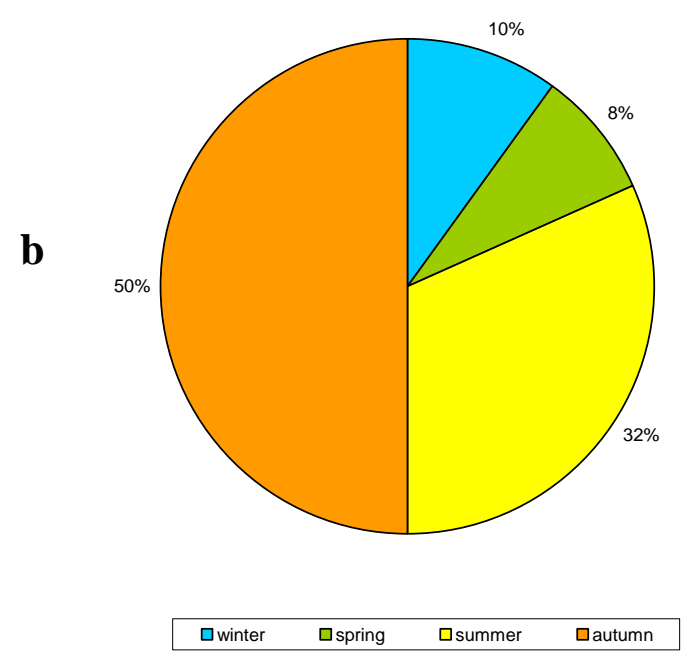

Fig. 4. Seasonal distribution of flood events recorded in Catalonia (1982-2007).

August (4 floods/century) and July (3 floods/century), while October showed a negative trend and the rest of the year did not show any trend.

Summer rainfall evolution does not experience any regional trend, although we must recognize the period 19942003 as the driest decade in the last century (Altava-Ortiz et al., 2010). The analysis of monthly rainfall evolution for some stations located on the coast (Llasat et al., 2009b) as well as the analysis of daily precipitation maxima corroborate this lack of trend (Barrera et al., 2006). 
Monhly distribution of flash floods and no flash floods events 1982-2007

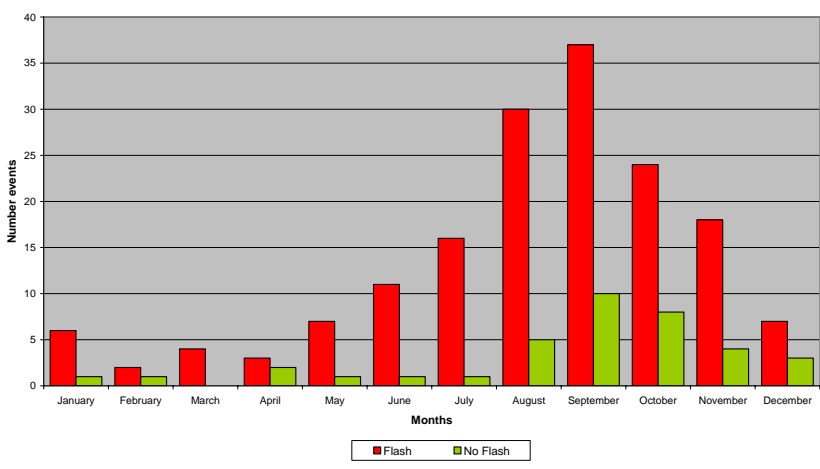

Fig. 5. Distribution of flash flood events and non flash-flood events recorded in Catalonia for the period 1982-2007.

Temporal evolution (1982-2007)

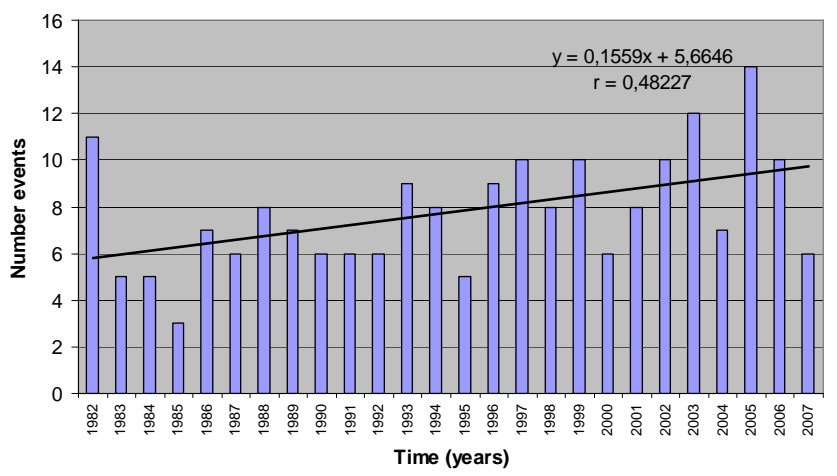

Fig. 6. Temporal evolution of flood events in Catalonia for the period 1982-2007.

\section{Impact analysis}

Figure 7 shows the distribution by categories: $52 \%$ of the total number of flood events can be classified as extraordinary floods, while $40 \%$ are only ordinary ones. Only $4.4 \%$ produced catastrophic floods during this period of study. $17 \%$ of the events produced one or more casualties (both extraordinary and catastrophic ones). October is the month that records the major percentage of catastrophic floods, although the maximum number of casualties has been recorded in September and August, usually as a consequence of an imprudent behaviour (Fig.8). No catastrophic floods have been recorded between December and May. A deep analysis has shown that all the catastrophic floods recorded during this period were produced by flash floods of type 2 .

Figure 9 shows the temporal evolution of floods by categories. It corroborates that the positive trend is consequence of the increase of extraordinary floods, essentially due to the greater occupation of flood-prone areas in the coastal region, as well as a decreased level of tolerance of the population (Llasat et al., 2009c). The comparison with the evolution of
Distribution of flood events by category $(0,1,2)(1982-2007)$

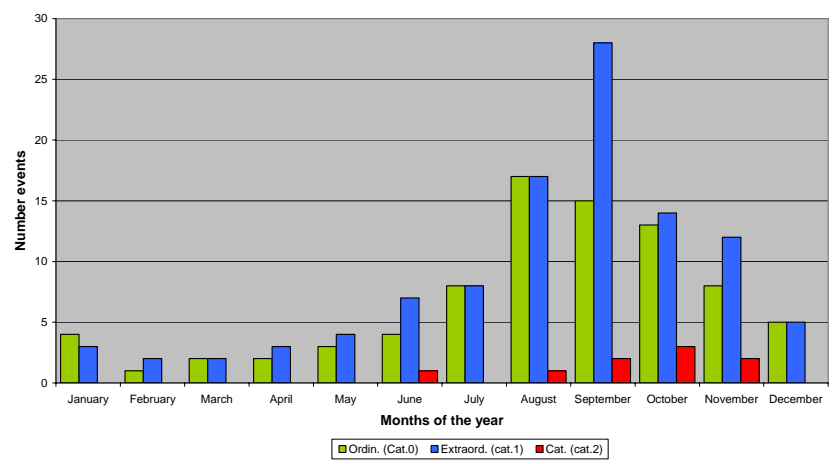

Fig. 7. Monthly distribution of floods in Catalonia taking into account their impact (1982-2007).

Monthly evolution of category 5 (1982-2007)

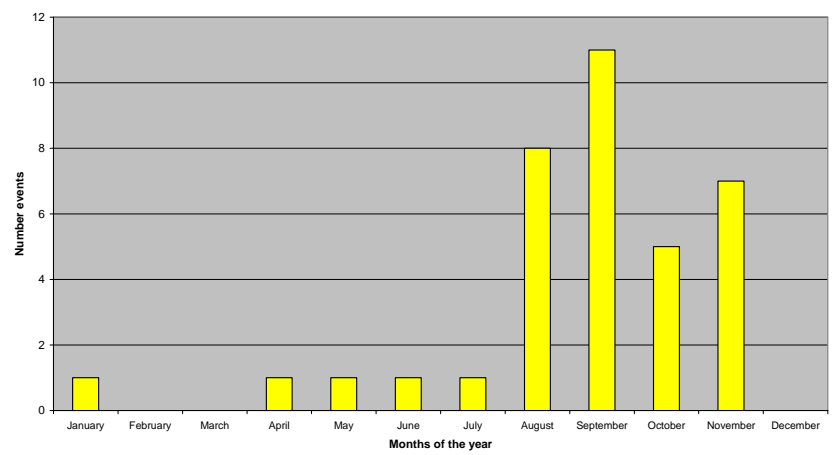

Fig. 8. Monthly distribution of casualties produced by floods in Catalonia (1982-2007).

population in Catalonia, which had near 5978600 inhabitants in 1986 and rose to 7210500 inhabitants in 2007, shows a correlation of 0.44 that improves when it only refers to coastal regions. Figure 10 shows the damage distribution in the Maresme region; the percentage for each type of damage has been calculated in basis to the rate between the flood events that have caused damages of this type and the total number of floods. Affected infrastructures are mainly roads, highways and railways. Some roads and paths had been built in the course of torrential rivers, or crossing them, as in the case of the coast railway. Affected cars refer to those that are carried away by flash-floods.

\section{Conclusions}

A database with information about the social impact produced by all the flood events recorded in Catalonia between 1982 and 2007 has been built. Social impact has been obtained systematically on the basis of news press data and, occasionally, on the basis of insurance data and technical and scientific reports. A total of 202 flood events have been 
Temporal evolution categories 0, 1, 2 (1982-2007)

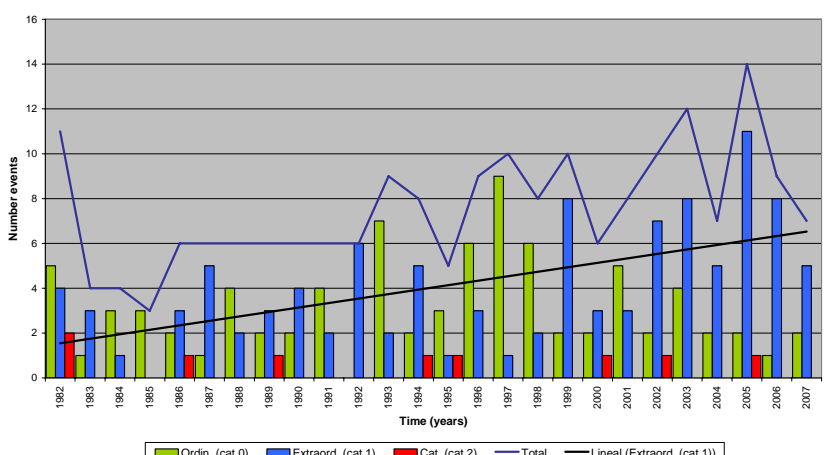

Fig. 9. Distribution of flood events by categories and annual evolution over the period 1982-2007.

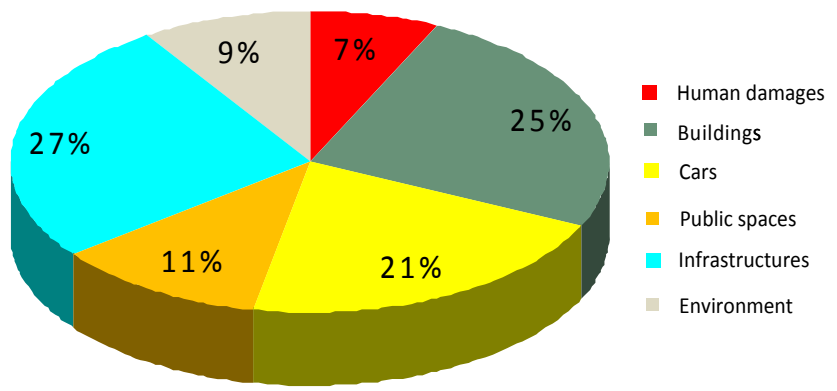

Fig. 10. Damage distribution in Maresme region for the period 1982-2007, as a consequence of flood events.

identified; of these, $82 \%$ of the events have produced flashfloods. September has recorded the maximum number of floods (23\%) followed by August and October with $17 \%$ and $16 \%$ of the total. This result points to an increase in the contribution of September to the annual number of flood events in comparison with the preceding period (before the 1980s), probably related with changes in population density (permanent and temporary residents) in flood-prone areas.

Considering the distribution by categories, less than 5\% of the flood event can be considered as catastrophic ones, $52 \%$ can be classified as extraordinary flood events, while $40 \%$ are only ordinary floods. $17 \%$ of the events produced one or more casualties. Catastrophic floods were concentrated between June and November, with October being the month that records the greatest percentage of them, probably due to the higher frequency of organized Mesoscalar Convective Systems and multicellular systems (Rigo and Llasat, 2007), which can sustain heavy precipitations over a long period, producing flash floods of type 2 . The positive trend detected in the annual number of extraordinary floods is a consequence of the greater occupation of flood-prone areas near the coast.
Acknowledgements. This research has been supported by the Sixth Framework Programme European Commission FLASH project (no. 036852) and the Spanish project SEVERUS (CGL200613372-C02-02). It has been done in the framework of the WMO Project MEDEX, and HYMEX.

Edited by: A. Mugnai

Reviewed by: one anonymous referee

\section{References}

Altava-Ortiz,V., Llasat, M. C., Ferrari, E., Atencia, A. and Sirangelo, B.: Monthly rainfall changes in the Central and Western Mediterranean Basins, at the end of the 20th and beginning of the 21 st centuries, Int. J. Climatol., 30, published online in Wiley InterScience, www.interscience.wiley.com, doi:10.1002/joc.2204, 2010.

Barnolas, M. and Llasat, M. C.: A flood geodatabase and its climatological applications: the case of Catalonia for the last century, Nat. Hazards Earth Syst. Sci., 7, 271-281, doi:10.5194/nhess-7271-2007, 2007.

Barrera, A., Llasat, M.C. and Barriendos, M.: Estimation of the extreme flash flood evolution in Barcelona County from 1351 to 2005, Nat. Hazards Earth Syst. Sci., 6, 505-518, doi:10.5194/nhess-6-505-2006, 2006.

Barriendos, M., Coeur, D., Lang, M., Llasat, M. C., Naulet, R., Lemaitre, F., and Barrera, A.: Stationarity analysis of historical flood series in France and Spain (14th-20th centuries), Nat. Hazards Earth Syst. Sci., 3, 583-592, doi:10.5194/nhess-3-5832003, 2003.

Blaikie, P., Cannon, T., Travis, I. and Wisner, B.: At Risk: Natural Hazards, People's vulnerability and Disasters, New York, Routledge, USA, 1994.

Brázdil, R., Glaser, R., Pfister, C., Antoine, J. M., Barriendos, M., Camuffo, D., Deutsch, M., Enzi, S., Guidoboni, E., and Rodrigo, F. S.: Flood events of selected rivers of Europe in the sixteenth century, Clim. Change, 43, 239-85, 1999.

Gaume E., Bain, V., Bernardaza, P., Newinger, O., Barbuc, M., Bateman, A., Blaškovicová, L., Blöschl, G., Borga, M., Dumitrescu, A., Daliakopoulos, I., Garcia, J., Irimescu, A., Kohnova, S., Koutroulis, A., Marchi, L., Matreata, S., Medina, V., Preciso, E., Sempere-Torres, D., Stancalie, G., Szolgay, J., Tsanis, J., Velasco, D., and Viglione, A.: A compilation of data on European flash floods, J. Hydrol., 367, 70-78, 2009.

Glaser, R. and Stangl, H.: Historical floods in the Dutch Rhine Delta, Nat. Hazards Earth Syst. Sci., 3, 605-613, doi:10.5194/nhess-3-605-2003, 2003.

Guijarro, J. A.: Some climatological aspects of heavy rainfall in mediterranean Spain, INM/WMO International Symposium on cyclones and hazardous weather in the Mediterranean, Mallorca, Spain, 14-19 April, 1997.

Llasat, M. C.: An objective classification of rainfall events on the basis of their convective features: application to rainfall intensity in the Northeast of Spain, Int. J. Climatol., 21, 1385-1400, 2001.

Llasat, M. C. and Rodríguez, R.: Extreme rainfall events in Catalonia: the case of 12 November, Nat. Hazards, 5, 133-151, 1992.

Llasat, M. C., Rigo, T., and Barriendos, M.: The "Montserrat2000"flash-flood event: a comparison with the floods that have 
occurred in the north-eastern Iberian peninsula since the 14th century, Int. J. Climatol., 23, 453-469, 2003

Llasat, M. C., Rigo, T., and Barriendos, M.: Floods in Catalonia (NE Spain) since the 14th century. Climatologial and meteorological aspects from historical documentary sources and old instrumental records, J. Hydrol., 313, 32-47, 2005.

Llasat, M. C., López, L., Barnolas, M., and Llasat-Botija, M.: Flash-floods in Catalonia: the social perception in a context of changing vulnerability, Adv. Geosci., 17, 63-70, doi:10.5194/adgeo-17-63-2008, 2008.

Llasat, M. C.: High magnitude storms and floods, in: The Physical Geography of the Mediterranean, edited by: Woodward, J. C., Oxford University Press, Oxford, 513-540. 2009.

Llasat, M. C., Atencia, A., Garrote, L., and Mediero, L.: The hydrometeorological forecasting in the framework of the european project FLASH, La Houille Blanche, 6, 66-71, doi:10.1051/lhb/2009080, 2009a.

Llasat, M. C., Llasat-Botija, M., and López, L.: A press database on natural risks and its application in the study of floods in Northeastern Spain, Nat. Hazards Earth Syst. Sci., 9, 2049-2061, doi:10.5194/nhess-9-2049-2009, 2009 b.

Llasat, M. C., Llasat-Botija, M., Barnolas, M., López, L., and Altava-Ortiz, V.: An analysis of the evolution of hydrometeorological extremes in newspapers: the case of Catalonia, 1982-2006, Nat. Hazards Earth Syst. Sci., 9, 1201-1212, doi:10.5194/nhess-9-1201-2009, 2009c.
Llasat, M.C. y F. Siccardi. A reflection about the social and technological aspects in flood risk management - the case of the Italian Civil Protection. Nat. Hazards Earth Syst. Sci., 10, 109-119, doi:10.5194/nhess-10-109-2010, 2010.

Messner, F. and Meyer, V.: Flood damage, vulnerability and risk perception - Challenges for flood damage research, Flood Risk Management: Hazards, Vulnerability and Mitigation Measures, edited by: Schanze, J., Zeman, E., and Marsalek, J., Springer, 149-167, 2006.

Pascual, R.: Estudio de precipitaciones intensas en la comarca catalana del Maresme. Nota técnica CMT de Catalunya no. 1, Instituto Nacional de Meteorología, 51 pp., 1999.

Ramis, C., Llasat, M. C., Genovés, A., and Jansà, A.: The october87 floods in Catalonia. synoptic and mesoscale mechanisms, Meteorol. Appl., 1, 337-350, 1994.

Rigo, T. and Llasat, M. C.: A methodology for the classification of convective structures using meteorological radar: Application to heavy rainfall events on the Mediterranean coast of the Iberian Peninsula, Nat. Hazards Earth Syst. Sci., 4, 59-68, doi:10.5194/nhess-4-59-2004, 2004.

Rigo, T. and Llasat, M. C.: Analysis of mesoscale convective systems in Catalonia using meteorological radar for the period 1996-2000, Atmos. Res., 83, 458-472, 2007. 